\title{
Measurement of Ozone Production Sensor
}

\author{
M. Cazorla and W. H. Brune \\ Department of Meteorology, Pennsylvania State University, PA 16802, USA
}

Received: 1 December 2009 - Published in Atmos. Meas. Tech. Discuss.: 22 December 2009

Revised: 18 April 2010 - Accepted: 20 April 2010 - Published: 3 May 2010

\begin{abstract}
A new ambient air monitor, the Measurement of Ozone Production Sensor (MOPS), measures directly the rate of ozone production in the atmosphere. The sensor consists of two $11.3 \mathrm{~L}$ environmental chambers made of UVtransmitting Teflon film, a unit to convert $\mathrm{NO}_{2}$ to $\mathrm{O}_{3}$, and a modified ozone monitor. In the sample chamber, flowing ambient air is exposed to the sunlight so that ozone is produced just as it is in the atmosphere. In the second chamber, called the reference chamber, a UV-blocking film over the Teflon film prevents ozone formation but allows other processes to occur as they do in the sample chamber. The air flows that exit the two chambers are sampled by an ozone monitor operating in differential mode so that the difference between the two ozone signals, divided by the exposure time in the chambers, gives the ozone production rate. High-efficiency conversion of $\mathrm{NO}_{2}$ to $\mathrm{O}_{3}$ prior to detection in the ozone monitor accounts for differences in the $\mathrm{NO}_{\mathrm{x}}$ photostationary state that can occur in the two chambers. The MOPS measures the ozone production rate, but with the addition of NO to the sampled air flow, the MOPS can be used to study the sensitivity of ozone production to NO. Preliminary studies with the MOPS on the campus of the Pennsylvania State University show the potential of this new technique.
\end{abstract}

\section{Introduction}

Ground-level ozone $\left(\mathrm{O}_{3}\right)$, one of the main constituents of smog, causes serious breathing problems and aggravates respiratory diseases in humans (Ho et al., 2007). Ozone also damages the foliage of croplands and forests (Madden and Hogswett, 2001). On a regional-to-global scale, groundlevel ozone contributes to climate change by acting as a

Correspondence to: M. Cazorla (mxc528@psu.edu) greenhouse gas (Foster et al., 2007). Ever since the cause of ground-level ozone was found to involve the chemistry of volatile organic compounds (VOCs) and nitrogen oxides $\left(\mathrm{NO}_{\mathrm{x}}\right)$ in the presence of sunlight (Haagen-Smit et al., 1953), significant effort has gone into determining the best strategies to reduce ozone levels in the ambient air (Sillman, 1993; NRC, 1991). In 1970, the Environmental Protection Agency (EPA) established a national ambient air quality standard (NAAQS) for ozone and mandated a monitoring network to assess the effectiveness of efforts to meet the standard. At the same time, EPA initiated the use of models to determine how best to regulate VOCs and $\mathrm{NO}_{\mathrm{x}}$ in order to control ozone. Initial strategies focused on the reduction of VOC emissions, but more recent strategies include the reduction of $\mathrm{NO}_{\mathrm{x}}$ emissions to meet the ozone NAAQS (Gégo, 2007).

In the presence of sunlight, nitrogen dioxide $\left(\mathrm{NO}_{2}\right)$ photolyzes, leading to the formation of ozone and nitric oxide (NO). After these two molecules are formed, they recombine to regenerate $\mathrm{NO}_{2}$ which will once again undergo photolysis. This continuous process is known as $\mathrm{NO}_{\mathrm{x}}$ photostationary state (PSS) and does not result in ozone production. New ozone is formed outside of the PSS when an atmospheric pool of peroxy radicals $\left(\mathrm{HO}_{2}\right.$ and $\left.\mathrm{RO}_{2}\right)$ alter the PSS by reacting with $\mathrm{NO}$ and producing new $\mathrm{NO}_{2}$. The main source of peroxy radicals is the reaction of the hydroxyl radical $(\mathrm{OH})$ with VOCs. Several studies show in detail chemical mechanisms for ozone production (for example, Finlayson-Pitts and Pitts Jr., 1977; Logan et al., 1981; Gery et al., 1989; NRC, 1991). The chemical production of ozone, $p\left(\mathrm{O}_{3}\right)$, can be calculated by means of Eq. (1) where the $k$ terms correspond to the effective rate coefficient for the reactions of peroxy radicals with NO.

$$
p\left(\mathrm{O}_{3}\right)=k_{\mathrm{NO}+\mathrm{HO}_{2}}[\mathrm{NO}]\left[\mathrm{HO}_{2}\right]+\sum k_{\mathrm{NO}+\mathrm{RO}_{2 \mathrm{i}}}[\mathrm{NO}]\left[\mathrm{RO}_{2}\right]_{i},
$$

The chemistry of ozone formation is sensitive to the ambient levels of $\mathrm{NO}_{\mathrm{x}}$ and VOCs. Since $\mathrm{HO}_{2}$ depends on

Published by Copernicus Publications on behalf of the European Geosciences Union. 
NO, Eq. (1) shows that the dependence of ozone formation on these two sets of precursors is non-linear. Hence, ozone can be formed under a regime limited by $\mathrm{NO}_{\mathrm{x}}$ or by VOCs (Kleinman, 2005). Theoretical calculations indicate that ozone production grows steadily up to a peak value as the mixing ratio of $\mathrm{NO}$ increases up to about $1 \mathrm{ppbv}$. After this point, the theoretical model indicates that ozone production decreases with increasing $\mathrm{NO}$ as the regime of ozone production becomes VOC-limited, which is also called $\mathrm{NO}_{\mathrm{x}}-$ saturated (Kleinman, 2002).

The ozone budget, Eq. (2), shows that ozone production depends on the ambient air chemistry, surface deposition, and local meteorology.

$$
\frac{\partial\left[\mathrm{O}_{3}\right]}{\partial t}=\underbrace{p_{\mathrm{O}_{3}}-l_{\mathrm{O}_{3}}}_{P\left(\mathrm{O}_{3}\right)} \underbrace{-\frac{v}{H}\left[\mathrm{O}_{3}\right]}_{S D}+\underbrace{u_{i} \frac{\partial\left[\mathrm{O}_{3}\right]}{\partial x_{i}}}_{A}
$$

$P\left(\mathrm{O}_{3}\right)$ is net chemical production consisting of chemical ozone production, $p_{\mathrm{O}_{3}}$, and chemical loss, $l_{\mathrm{O}_{3}}$, SD is surface deposition consisting of the deposition velocity, $v$, divided by the mixed layer height, $H$, times the ozone concentration, and $A$ is advection consisting of the velocity in three directions, $u_{i}$, times the ozone gradient in those three directions.

Meteorological conditions play an important role in the local ozone budget. Transport processes such as horizontal advection and turbulence can modify substantially the accumulation of ozone over time in the atmosphere. For instance, a typical meteorological scenario that causes high ozone episodes in heavily polluted urban centers is light or no wind combined with strong solar radiation and high temperature. In such conditions, the term responsible for the accumulation of ozone in the ambient air is the net chemical rate of ozone production $P\left(\mathrm{O}_{3}\right)$. Additionally, in the same equation, the surface deposition and advection of ozone are proportional to the ambient ozone concentration $\left[\mathrm{O}_{3}\right]$ that is produced predominately by the local photochemistry. Hence, if the net ozone production $P\left(\mathrm{O}_{3}\right)$ can be decreased by regulatory actions, the overall ozone level over time will decrease proportionally.

The contribution of the transport terms for the case of suburban areas located downwind of pollution centers is much greater than in the case described above. Likewise, areas located on the path of influential meteorological features such as low level jets or high pressure systems are directly affected by ozone advection (Taubman et al., 2008; Kemball-Cook et al., 2009). In these particular situations, high concentrations of ambient ozone would come from transport of ozone rather than local ozone production. At present, however, it is difficult to determine in a quantitative way the importance of ozone transport versus ozone production for regions that are monitored by air quality networks.

All the terms in Eq. (2) need to be known to a high degree of accuracy in order for models to yield a good approximation of the rate of ozone production. Uncertainties in the chemical mechanisms, hydrocarbon inventories, ozone transport, and mathematical algorithms, however, represent potential sources of error in the estimation of modeled rates of ozone production (NRC, 1991).

One concern about using constrained photochemical models for determining ozone production is the difference between the modeled and calculated ozone production, $P\left(\mathrm{O}_{3}\right)$ (Martinez et al., 2003; Ren et al., 2003; Ren et al., 2004; Shirley et al., 2006; Kanaya et al., 2007). For several field studies, the modeled $\mathrm{HO}_{2}$ is less than measured $\mathrm{HO}_{2}$ at high NO levels, which affects directly the modeled ozone production (Eq. 1). In these field studies, ozone production that is calculated from measured $\mathrm{HO}_{2}$ and $\mathrm{NO}$ is less than ozone production calculated from modeled $\mathrm{HO}_{2}$ for $\mathrm{NO}$ less than about 1 ppbv, becomes about equal when $\mathrm{NO}$ is about $1 \mathrm{ppbv}$, and becomes increasingly greater as NO increases above about $1 \mathrm{ppbv}$. The daily cumulative ozone, which is found by integrating the ozone production rate for each day, is as much as 1.5 times larger for ozone production calculated with measured $\mathrm{HO}_{2}$ compared to that calculated with modeled $\mathrm{HO}_{2}$ (Ren et al., 2003). However, there is presently no definitive evidence for or against this greater ozone production rate calculated using measured $\mathrm{HO}_{2}$.

A second concern is that the models used to simulate ozone have significant uncertainties and need to be tested not only with observed ozone values but also with measured indicators for determining if the ozone production is $\mathrm{NO}_{\mathrm{x}}{ }^{-}$ limited or VOC-limited. A number of indicators have been proposed, including the ratio of peroxide $\left(\mathrm{H}_{2} \mathrm{O}_{2}\right)$ to nitric acid $\left(\mathrm{HNO}_{3}\right)$ in the ambient air (Sillman, 1995; Kleinman et al., 1997). In addition, radical propagation studies have introduced the fraction of $\mathrm{OH}$ radicals that react with hydrocarbons and the fraction of $\mathrm{HO}_{2}$ radicals that react with $\mathrm{NO}$ as potential indicators of the regime of ozone production (Tonnesen and Dennis, 2000). Finding indicators that work well even in controlled environmental chambers, however, is proving to be difficult, so that no indicator methods have yet been widely deployed.

A direct measurement of ozone production can address the different questions discussed above. First, direct measurements of ozone production could be added to existing air quality networks to provide important information for the design of air quality regulations. Second, they could be used to quantify the importance of ozone transport versus ozone production by comparing the direct measurement of ozone production to the observed ozone rate-of-change. Third, they would contribute to the understanding of the $\mathrm{NO}_{\mathrm{x}}$ and VOC sensitivity of ozone production. Fourth, they could help resolve the discrepancy between the ozone production calculated from measured and modeled $\mathrm{HO}_{2}$. Finally, a direct measurement of ozone production would help improve chemical transport models.

We have developed an instrument to measure directly the atmospheric ozone production rate. The Measurement of Ozone Production Sensor, MOPS, samples ambient air 


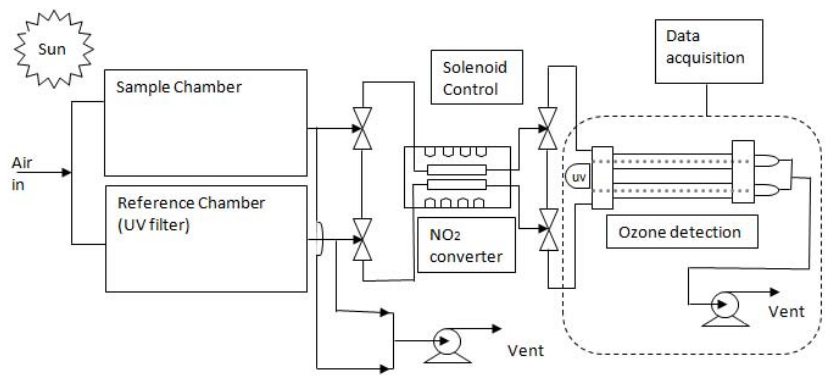

Fig. 1. Schematic of the MOPS. Equal air flows pass through the two chambers exposed to sunlight. The sample chamber passes solar ultraviolet light while the reference chamber has a film covering that blocks it. $\mathrm{NO}_{2}$ converter cells enable the detection of $\mathrm{NO}_{2}+\mathrm{O}_{3}$ by the dual-channel UV-absorption $\mathrm{O}_{3}$ monitor.

continuously and yields the net rate of ozone production. This paper discusses the MOPS, its concept, operation, testing, and initial measurements at the Pennsylvania State University.

\section{Experimental methods}

\subsection{Principles of a direct ozone production measurement}

The measurement of ozone production sensor (MOPS) has three components: two environmental chambers continuously exposed to solar radiation, a nitrogen dioxide-to-ozone conversion unit, and a modified ozone analyzer. A schematic of the instrument is shown in Fig. 1.

The sample chamber's Teflon walls transmit solar ultraviolet light so that the air in the sample chamber undergoes the same photochemistry that takes place in the ambient air. The reference chamber has a film that blocks radiation of wavelengths less than $400 \mathrm{~nm}$. As a result, the reference chamber limits the production of hydroxyl radicals $(\mathrm{OH})$ generated by the photolysis of ozone followed by the reaction with water vapor. The photolysis of nitrous acid (HONO), a source of $\mathrm{OH}$ radicals, is also constrained. Similarly, the film on the reference chamber restricts the production of hydroperoxy radicals $\left(\mathrm{HO}_{2}\right)$ produced by the photolysis of formaldehyde (HCHO). With radical chemistry eliminated, the only ozone in this chamber comes from the photostationary state (PSS) of the species $\mathrm{NO}, \mathrm{NO}_{2}$, and $\mathrm{O}_{3}$. Since it is not possible to eliminate radical production without affecting $\mathrm{NO}_{2}$ photolysis near $400 \mathrm{~nm}$, the PSS in the reference chamber tends to shift $\mathrm{O}_{3}$ toward $\mathrm{NO}_{2}$. The total amount of ozone in the reference chamber, therefore, is conserved in the form of $\mathrm{NO}_{2}$ plus $\mathrm{O}_{3}$.

Some of the ozone produced in the sample chamber reacts with ambient $\mathrm{NO}$ and is partitioned into $\mathrm{NO}_{2}$ according to the $\mathrm{NO}_{\mathrm{x}}$ PSS. At the same time, differences in the $\mathrm{NO}_{2}$ photolysis in the two chambers could cause the partitioning of ozone and $\mathrm{NO}_{2}$ in the two chambers to be different. The difference, nevertheless, between the total sum $\mathrm{NO}_{2}+\mathrm{O}_{3}$ in the sample chamber minus the sum in the reference chamber cancels out the PSS component of ozone production and yields only the component associated with the production of new ozone by radical chemistry.

The strategy, therefore, is to determine the differential of the sum $\mathrm{O}_{3}+\mathrm{NO}_{2}$ between the two chambers and divide it by the exposure time, $\tau$, of the air inside them by means of Eq. (3) to determine the ozone production rate.

$P\left(\mathrm{O}_{3}\right)=\Delta \mathrm{O}_{3} / \tau$

$P\left(\mathrm{O}_{3}\right)$ is the net chemical ozone production, $\Delta \mathrm{O}_{3}$ is the difference in $\mathrm{O}_{3}+\mathrm{NO}_{2}$ between the sample and reference chamber after the $\mathrm{NO}_{2}$ has been converted into $\mathrm{O}_{3}$.

\subsection{Technical details of MOPS}

Air is sampled by both chambers through a common short Teflon inlet. The flow is split equally between the two chambers, which are identical in size and flow characteristics.

Two hollow cylindrical aluminum frames $(17.78 \mathrm{~cm}$ diameter and $45.752 \mathrm{~cm}$ long) serve as support for Teflon film (FEP, $0.05 \mathrm{~mm}$ thick) that is wrapped around the frames. The volume of the chambers is $11.3 \mathrm{~L}$ and the flow of ambient air through each chamber is $1.5 \mathrm{~L} / \mathrm{min}$. The inlets and outlets to the chambers are pieces of Teflon tubing $2.54 \mathrm{~cm}$ diameter and $6.35 \mathrm{~cm}$ long. The flow is induced by a pump located downstream of the chambers. The sample chamber is clear Teflon so the air inside is radiated by all the wavelengths of the solar radiation that occur in the atmosphere. The reference chamber, made the same as the sample chamber, is covered with an Ultem film (polyetherimide, $0.25 \mathrm{~mm}$ thick) that removes sunlight at wavelengths less than $400 \mathrm{~nm}$.

Since the goal is to detect the difference in $\mathrm{NO}_{2}+\mathrm{O}_{3}$ between the sample and reference air, the flows that exit the chambers enter an $\mathrm{NO}_{2}$-to- $\mathrm{O}_{3}$ converter unit. This converter unit uses two photolytic conversion cells, one for the air from the sample chamber and one for the air from the reference chamber. A light-emitting diode ( $395 \mathrm{~nm}$ wavelength, 5.4 watts of power) is attached to the end of each photolytic conversion cell as the source of radiation. The photolytic conversion cells are made of quartz with a reflective aluminum mirror coating on the outside. The dimensions of the cells are $30.5 \mathrm{~cm}$ in length and $5.1 \mathrm{~cm}$ in diameter. Light is also reflected by a round aluminum mirror placed at the end of each quartz cell opposite the light source. This dual cell conversion unit is directly attached to a differential ozone monitor. The converter unit uses the internal pump inside the ozone monitor to pull air so that the flow through each photolytic conversion cell is the same as the flow through each detection cell in the ozone monitor. This flow is $0.5 \mathrm{~L} / \mathrm{min}$. The residence time in each photolytic conversion cell is $103 \pm 14$ seconds $(95 \%, N=4)$ as determined by ozone pulse experiments described later. 
After the conversion of $\mathrm{NO}_{2}$ into $\mathrm{O}_{3}$ has taken place, the MOPS uses a modified ozone monitor (Thermo Scientific, Model 49i) to obtain a differential measurement of the ozone between the two chambers. The main modification applied to the commercial dual channel ozone monitor is the removal of the ozone scrubber. By doing so the ozone differential monitor receives a continuous supply of sample air from the sample chamber and reference air from the reference chamber and detects the ozone differential in ppbv. Additionally, the temperature of the two UV absorption cells in the ozone monitor was stabilized by an aluminum block that was clamped tightly around the two absorption cells.

To account for the possible differences between the two photolytic conversion cells in the conversion unit, the flows of sample and reference air switch photolytic conversion cells every $5 \mathrm{~min}$. To switch flows, the instrument has two pairs of solenoid valves. The first pair is located between the chambers and the conversion cells. The second pair of solenoid valves works synchronously with the first pair and is located between the conversion cells and the ozone monitor. In this way, the sample channel in the ozone instrument always measures the ozone from the sample chamber. The final reading is obtained as an average of the ozone differential measured with each of the photolytic conversion cells switched to the sample chamber, giving an instrument time constant of twice $5 \mathrm{~min}$, or $10 \mathrm{~min}$.

The instrument uses a LabVIEW application for data acquisition and solenoid control. This application acquires additional information such as the temperature inside the MOPS chambers and the ambient $\mathrm{NO}_{\mathrm{x}}$ mixing ratios that are measured by a NO-NO $2-\mathrm{NO}_{\mathrm{x}}$ analyzer (Thermo Scientific, Model 42C) that samples air near the MOPS.

\subsection{MOPS characterization}

The quantitative measurement of ozone production depends on the following factors: knowing the residence time in the chambers; having the atmospheric ozone production occurring in the sample chamber but not the reference chamber; measuring accurately the differences in the sum of $\mathrm{O}_{3}$ and $\mathrm{NO}_{2}$; and having all photochemistry that does not produce ozone but can affect the sum of $\mathrm{O}_{3}$ and $\mathrm{NO}_{2}$ be the same in the two chambers so that the differential measurement is not biased.

\subsubsection{Mean exposure time}

The ozone production measurement depends linearly on the exposure time. For a flow of $1.5 \mathrm{~L} / \mathrm{min}$ through each $11.3 \mathrm{~L}$ chamber, the mean exposure time would be $7.5 \mathrm{~min}$ for a perfect plug flow. Ideally, the aim is to have plug flow so that the time spent in the chamber is the same for every air molecule.

The mean exposure time in the MOPS chambers was determined by adding a short pulse of ozone to the chambers and then monitoring the ozone at the exit. The pulse ex-

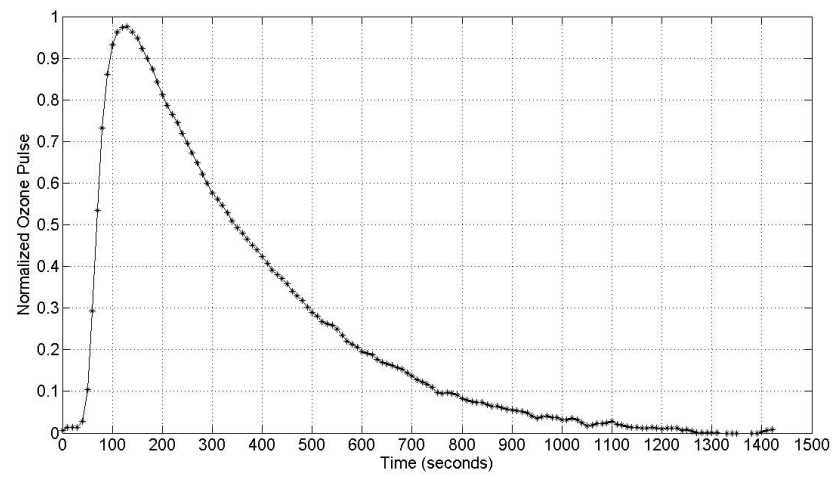

Fig. 2. Normalized mean ozone pulse for a series of four pulse experiments. A $20-\mathrm{s}_{3}$ pulse was added at time $=0 \mathrm{~s}$ and $\mathrm{O}_{3}$ was monitored at the output of the chamber. The pulses are normalized so that the peak value is 0.975 .

periment not only helps determine the mean exposure time but also helps diagnose the type of flow inside the chambers. A normalized mean ozone distribution for a series of four pulses is shown in Fig. 2. The mean time obtained through this method is $5.8 \pm 0.3 \mathrm{~min}(95 \%, N=4)$.

In addition to the pulse experiment, reactions with known amounts of ozone and excess $\alpha$-pinene and ethene were performed independently. The decay of ozone was monitored over time until it decreased to a steady value greater than zero. This steady-state ozone value represents the average concentration remaining from ozone that has experienced reaction times distributed according to the distribution function depicted in Fig. 2. For example, while more ozone experienced 130 seconds of reaction than ozone did for any other time, some ozone experienced reaction for 1000 seconds or more. The mean ozone mixing ratio is equal to the integral of the normalized mean pulse distribution multiplied by the exponential decay of ozone. The calculated mean ozone ratios agree to within $10 \%$ of the observed steady-state ozone that results from the reaction with $\alpha$-pinene or ethene. The mean time was then calculated using the mean ozone mixing ratio, the initial ozone mixing ratio, and the rate coefficients. This calculated time agrees with the time required for the reactions to achieve steady state to within 5\%. Finally, this same calculated time agrees with the time from the pulse experiment to within $10 \%$.

The results obtained from these experiments indicate that, for the current version of the MOPS chambers, the mean exposure time is less than the time calculated for perfect plug flow by $1.7 \mathrm{~min}$. This feature is caused by a fast jet of air that enters the chamber through a wide inlet $(2.54 \mathrm{~cm})$ located at the center of the circular 17.78-cm diameter face of the chamber and exits through a similar outlet located on the other end. Further evidence for this jet is the peak ozone concentration in Fig. 2 that appears at about 2 min. The pulse in Fig. 2, also indicates that there is turbulence and probably 
uneven mixing that yield the tail of ozone distribution. The bulk of the ozone molecules, however, leave the chamber at a mean time of $5.8 \pm 0.3 \mathrm{~min}$.

\subsubsection{Radical abundances inside the chambers}

One of the potential biases associated with the measurement of the rate of ozone production involves the abundances of the radicals $\mathrm{OH}, \mathrm{HO}_{2}$, and $\mathrm{RO}_{2}$ inside the chambers. The radical abundances in the sample chamber should be the same as in the atmosphere, while the $\mathrm{OH}$ and $\mathrm{HO}_{2}$ abundances in the reference chamber should be zero. Because ozone is produced by the reaction of $\mathrm{HO}_{2}$ and $\mathrm{RO}_{2}$ radicals with $\mathrm{NO}$, as shown in Eq. (1), an effective way to determine to what extent the proposed technique yields a quantitative measurement of ozone production is to compare the radical abundances inside the MOPS chambers with respect to the abundances in a controlled environment.

The strategy to determine radical loss was to create an artificial atmosphere in an environmental chamber and measure $\mathrm{OH}$ and $\mathrm{HO}_{2}$ in it. The sample chamber was placed in this artificial atmosphere and the radical concentrations were measured. The same procedure was followed with the reference chamber. A final measurement of $\mathrm{OH}$ and $\mathrm{HO}_{2}$ radicals in the empty artificial atmosphere was obtained to confirm the initial measurement of radicals. This experiment was completed by flowing air with $60 \mathrm{ppbv}$ of ozone and $40 \%$ of relative humidity into an environmental chamber consisting of a $100 \mathrm{~L}$ Teflon FEP film bag with metal endplates and exposing it to external ozone-free mercury lamps to produce $\mathrm{OH}$ and $\mathrm{HO}_{2}$ and black lights to set the $\mathrm{NO}_{\mathrm{x}}$ photostationary state. The $\mathrm{OH}$ and $\mathrm{HO}_{2}$ radicals were measured with the Ground-based Tropospheric Hydrogen Oxides Sensor (GTHOS) (Faloona et al., 2004), which was attached to one of the ends of the large environmental chamber. The GTHOS sampling flow was $1 \mathrm{~L} / \mathrm{min}$, similar to the flow in MOPS. GTHOS sampled air directly from the artificial atmosphere and then from each MOPS chamber when they were placed inside the environmental chamber.

The $\mathrm{HO}_{2}$ radical abundance found in the MOPS sample chamber agreed with the abundance in the artificial atmosphere to within 5\%. In the reference chamber (Ultem coated), the abundance of $\mathrm{HO}_{2}$ radicals decreased to less than $10 \%$ of its initial value. $\mathrm{RO}_{2}$ was not measured, but because $\mathrm{RO}_{2}$ has reactions similar to those for $\mathrm{HO}_{2}$, it is likely that the behavior of $\mathrm{RO}_{2}$ is similar to the observed behavior of $\mathrm{HO}_{2}$. The abundance of $\mathrm{OH}$ in the clear chamber was half of the abundance in the artificial atmosphere. The decrease in $\mathrm{OH}$ and no change in $\mathrm{HO}_{2}$ indicate that the $\mathrm{HO}_{\mathrm{x}}$ production is the same as in the artificial atmosphere but the sample chamber may contain some additional OH loss. This difference in $\mathrm{OH}$ radicals, however, does not impact the rate of ozone production, as it can be observed in Eq. (1). In the reference chamber, the $\mathrm{OH}$ abundance decreased to virtually zero, as expected. These results indicate that the ozone-producing photochemistry in the sample chamber is similar to that in the artificial atmosphere while the ozone producing photochemistry in the reference chamber is reduced to less than $10 \%$ of ambient.

\subsubsection{Measurement of photolysis frequencies}

In addition to these radical measurements, radiometric measurements were made in both chambers. The photolysis frequencies of the species $\mathrm{NO}_{2}, \mathrm{O}_{3}$, and $\mathrm{HONO}$ were measured using a Scanning Actinic Flux Spectroradiometer (SAFS) by B. Lefer at the University of Houston (Shetter and Muller, 1999; Shetter et al., 2002). The measurements were performed on a sunny day, 14 May 2009, at noon on the roof of the Moody Towers at the University of Houston.

The blockage of UV light by the Ultem film in the reference chamber was assessed by comparing the ambient radiometric measurements against the measurements obtained inside the reference chamber. A similar measurement and comparison were performed for the clear sample chamber. The results for the sample and reference chambers are shown in Table 1. When the radiometer was introduced in the reference chamber coated with Ultem film, the photolysis frequencies for $\mathrm{O}_{3}, \mathrm{NO}_{2}$, and $\mathrm{HONO}$ dropped to less than $2 \%$ of the ambient values. In contrast, the photolysis frequencies measured inside the sample chamber remained within $3 \%$ of ambient values. These results confirm the radical measurements performed in the MOPS chambers and support the validity of the technique in terms of restricting radical formation in the reference chamber while conserving radical photochemistry in the sample chamber.

\subsection{4 $\quad \mathrm{NO}_{2}$ conversion efficiency}

The conversion efficiency of the photolytic converter unit was tested for different levels of $\mathrm{NO}_{2}$ and is shown in Table 2. These results indicate that for most atmospheric abundances of $\mathrm{NO}_{2}$ the efficiency of the conversion unit is $88 \%$ or higher. The conversion of $\mathrm{NO}_{2}$ decreases as $\mathrm{NO}_{2}$ increases because the rate of $\mathrm{NO}+\mathrm{O}_{3} \rightarrow \mathrm{NO}_{2}+\mathrm{O}_{2}$ increases to stay in photostationary state with the greater $\mathrm{NO}_{2}$ photolysis rate, thus shifting the $\mathrm{NO}_{\mathrm{x}}$ photostationary state away from $\mathrm{O}_{3}$ and toward $\mathrm{NO}_{2}$. At $88 \%$ conversion efficiency, the calculated photolysis rate from the exponential decay of $\mathrm{NO}_{2}$ is 0.09 to $0.1 \mathrm{~s}^{-1}$. In contrast, a typical atmospheric value for the $\mathrm{NO}_{2}$ photolysis frequency is $0.008 \mathrm{~s}^{-1}$ at midday on a sunny day.

To ensure that the $\mathrm{NO}_{2}$ conversion cells are sufficient to allow accurate ozone production measurements, a simple computer model that includes the $\mathrm{NO}_{\mathrm{x}}$ photostationary state and the new production of ozone from the reaction $\mathrm{HO}_{2}$ plus $\mathrm{NO}$ was run for typical atmospheric conditions. Inputs for the model were concentrations of $\mathrm{O}_{3}, \mathrm{NO}, \mathrm{NO}_{2}$ and $\mathrm{HO}_{2}$ that were measured in Houston during the Texas Radical and Aerosol Measurement Project (TRAMP) in 2006. The 
Table 1. Measurement of photolysis frequencies, $J\left(\mathrm{~s}^{-1}\right)$, in the ambient air and the MOPS chambers. The shaded areas indicate photolysis frequencies measured inside the reference chamber (U1tem coated). Clear areas in the second and third columns correspond to measurements inside the sample chamber (clear). The last column shows the transmission of chamber measurements with respect to the ambient.

\begin{tabular}{llll}
\hline & Ambient & Chamber & Transmission \\
\hline$J \mathrm{NO}_{2}$ & $7.70 \mathrm{E}-03$ & $7.50 \mathrm{E}-03$ & 0.974 \\
& $7.00 \mathrm{E}-03$ & $1.50 \mathrm{E}-04$ & 0.021 \\
$J \mathrm{HONO}$ & $1.66 \mathrm{E}-03$ & $1.62 \mathrm{E}-03$ & 0.976 \\
& $1.50 \mathrm{E}-03$ & $1.00 \mathrm{E}-05$ & 0.0067 \\
$J_{3}$ & $2.88 \mathrm{E}-05$ & $2.85 \mathrm{E}-05$ & 0.991 \\
& $2.60 \mathrm{E}-05$ & $1.50 \mathrm{E}-07$ & 0.0058 \\
\hline
\end{tabular}

Table 2. Percentage of $\mathrm{NO}_{2}$ converted to ozone in the converter unit cells for different levels of $\mathrm{NO}_{2}$.

\begin{tabular}{ll}
\hline $\mathrm{NO}_{2}(\mathrm{ppb})$ & $\%$ Conversion \\
\hline 17 & 88 \\
25 & 83 \\
45 & 77 \\
75 & 66 \\
125 & 58 \\
\hline
\end{tabular}

concentrations chosen are representative of a polluted day in the morning, at noon, at the peak of temperature, and in the evening. The rate coefficients for the model were taken from the data published by the Jet Propulsion Laboratory (JPL) (Sander et. al, 2006).

Table 3 presents the cases analyzed and results for the production of ozone with converter, without converter and the theoretical calculation of new ozone in $\mathrm{ppbv} \mathrm{h}^{-1}$. The final columns are the difference between the MOPS measurement with the converter unit minus the theoretical calculation of new ozone and the ratio of the MOPS measurement with the converter unit to the theoretical calculation of new ozone.

The first case analyzed is the absence of production of new ozone, the concentration of $\mathrm{HO}_{2}$ is zero and the photostationary state of ozone remains unperturbed. Consequently, the model theoretical calculation cancels out exactly the photostationary state and the ozone production is zero, as expected. The ozone that exits the reference chamber has partitioned mostly towards $\mathrm{NO}_{2}$. Without the ozone converter unit, the modified ozone analyzer would be unable to see the ozone in the form of $\mathrm{NO}_{2}$ from the reference chamber and the result is an unrealistic ozone differential of $43.4 \mathrm{ppbv} \mathrm{h}^{-1}$ of ozone production. Adding the $\mathrm{NO}_{2}$ conversion in the converter unit minimizes the difference between the two chambers so the production of ozone is $0.0002 \mathrm{ppbv} \mathrm{h}^{-1}$.
Likewise, for the cases of ozone production due to the presence of $\mathrm{HO}_{2}$ radicals, model calculations show that without the conversion unit the ozone differential between chambers is overestimated when compared against the theoretical calculation. By adding the $\mathrm{NO}_{2}$ converter, the measurements become within $10 \%$ of theoretical values. The correction of the false signal is substantial such as the morning case in Table 3. Without the conversion unit, the ozone monitor would measure $92 \mathrm{ppbv} \mathrm{h}^{-1}$. The theoretical rate, however, corresponds to $26.9 \mathrm{ppbvh}^{-1}$. The MOPS result with the converter is within $10 \%$ of the calculated new ozone. A highly efficient conversion unit, therefore, helps avoid the loss of ozone in the form of $\mathrm{NO}_{2}$ and corrects a potential bias in the measurements.

\subsubsection{Artefact due to high relative humidity and $\mathrm{NO}_{2}$ loss}

Ideally, the only difference between the sample and reference chambers is the photolysis in the sample chamber that enables ozone production. All other characteristics should be the same, including flows, relaxation towards $\mathrm{NO}_{\mathrm{x}}$ photostationary state, and wall effects, so that any changes they induce in either ozone or $\mathrm{NO}_{2}$ cancel out in the differential ozone measurement. Thus, studies were devised to examine possible differences between the two chambers.

The wall loss of $\mathrm{O}_{3}$ found in the MOPS chambers is less than $3 \%$. For NO, the losses are less than $1 \%$. The wall losses of these two species were not found to be a potential interference with the measurement.

The wall loss of $\mathrm{NO}_{2}$ in the MOPS chambers was found to be significant for high relative humidity cases and for differences in relative humidity in the two chambers. This loss was studied by preparing $\mathrm{NO}_{2}$ mixtures with air and varying the relative humidity. During these experiments, as relative humidity increased, the concentration of measured $\mathrm{NO}_{2}$ decreased in a nonlinear fashion. For relative humidity higher than $50 \%$, more $\mathrm{NO}_{2}$ was removed as the relative humidity became higher. Previous research demonstrates that the uptake of water on a Teflon surface is about three times as much at $70 \%$ relative humidity as it is at $50 \%$ (Svensson et al., 1981). This condition of the Teflon surface has been proven to have an impact on the rate at which $\mathrm{NO}_{2}$ is removed at different relative humidities, resulting in nitric acid $\left(\mathrm{HNO}_{3}\right)$ formation and HONO off-gassing (Wainman et al., 2001). The experiments performed with the MOPS chambers confirm these findings.

The removal of $\mathrm{NO}_{2}$ in the chambers at high relative humidity directly affects the meaurement of ozone production. Since MOPS is a differential measurement instrument, uneven relative humidity values in the MOPS chambers could potentially trigger false ozone production signals. According to our laboratory studies, if the relative humidity in one of the chambers stays at about $30 \%$, the removal of $\mathrm{NO}_{2}$ is about 1 ppbv. In contrast, if the relative humidity in the second 
Table 3. Model results for ozone production $\left(\mathrm{ppbv} \mathrm{h}^{-1}\right.$ ) without converter unit (W/o C.U.), with converter unit (With C.U.), and theoretically calculated. The last columns are the difference between calculated production rates and modeled results with the converter unit and the ratio of the model results with the converter unit to the calculated ozone production rate. The residence time in the chambers is 5.8 min while the residence time in the converter cells is 103 seconds. The photolysis frequency inside converter is $0.09 \mathrm{~s}^{-1}$. The photolysis frequency in the atmosphere is $0.008 \mathrm{~s}^{-1}$ at noon. For the morning and evening cases, $J_{\mathrm{NO}_{2}}$ was assumed to be half of the noon value.

\begin{tabular}{llllllllll}
\hline & & \multicolumn{1}{c}{} & \multicolumn{5}{c}{ Ozone Production Rate $\left(\mathrm{ppbv} \mathrm{h}^{-1}\right)$} \\
\hline Case & $\mathrm{O}_{3}(\mathrm{ppb})$ & $\mathrm{NO}(\mathrm{ppb})$ & $\mathrm{NO}_{2}(\mathrm{ppb})$ & $\mathrm{HO}_{2}(\mathrm{ppt})$ & W/o C.U. & With C. U. & Calculated & Difference & Ratio \\
Zero & 45 & 5 & 10 & 0 & 43.4 & 0.0002 & 0 & -0.0002 & - \\
Morning & 15 & 5 & 20 & 6 & 92.1 & 23.8 & 26.9 & 3.1 & 0.88 \\
Noon & 98 & 2 & 10 & 60 & 71.4 & 54.8 & 54.8 & 0 & 1 \\
T peak & 120 & 1 & 10 & 110 & 81.7 & 69.3 & 70.3 & 1 & 0.99 \\
Evening & 45 & 0.5 & 20 & 45 & 84.8 & 57.9 & 63.1 & 5.1 & 0.92 \\
\hline
\end{tabular}

chamber is high, close to $80 \%$, the $\mathrm{NO}_{2}$ removal is about 7 ppbv. This uneven $\mathrm{NO}_{2}$ removal causes a differential of about $6 \mathrm{ppb}$ of $\mathrm{NO}_{2}$, which represent a false ozone production signal as high as $60 \mathrm{ppbvh}^{-1}$. This false background correlates with anomalous signals that were observed during evenings in Houston Texas in which the relative humidity of the air jumped suddenly to high values.

An additional test was performed to ensure that the anomalies are actually associated with relative humidity. Air containing $60 \mathrm{ppbv}$ of ozone, $60 \mathrm{ppbv}$ of $\mathrm{NO}_{2}$ and $94 \%$ relative humidity was prepared and sampled by the MOPS. The reference chamber was heated with an infrared lamp to decrease its relative humidity without altering the absolute humidity of the air flow. As the relative humidity in the sample chamber became higher, there was a negative value for the ozone differential due to $\mathrm{NO}_{2}$ removal.

The relative humidity can be different in the MOPS chambers due to differences in temperature in the two chambers. This difference is caused by the UV blocking film (Ultem) that covers the reference chamber. At the temperture peak during a hot summer day, the temperature in the clear sample chamber was as much as $5^{\circ} \mathrm{C}$ above the ambient temperature. The reference chamber was warmer than the sample chamber by another $\sim 6^{\circ} \mathrm{C}$, thus up to $11^{\circ} \mathrm{C}$ above the ambient temperature for the warmest cases. These temperature differences cause little difference for the ozone production rates, since the rate coefficients of the reactions of $\mathrm{HO}_{2}$ and $\mathrm{RO}_{2}$ with $\mathrm{NO}$ have at little temperature dependence. However, these temperature differences do translate into differences in relative humidity between the two chambers.

During daytime, the higher-than-ambient temperatures inside the MOPS chambers caused the relative humidity to be much less than $50 \%$. Experimental data indicate that for the most extreme daytime cases, which occur in the early morning, the interference due to $\mathrm{NO}_{2}$ removal can introduce a loss of about 1 ppbv out of 7 ppbv observed, or a $14 \%$ error, for the ozone differential. After early morning, the relative humidity decreases as the solar radiation intensifies and the artefact error becomes insignificant. Later in the evening or at night, however, the artefact can sometimes affect the measurements.

When the ambient temperature decreases in the evening, the relative humidity of the air increases. If the relative humidity is high but the same in both chambers, then any $\mathrm{NO}_{2}$ removal on the Teflon film surfaces and HONO off-gassing will mostly cancel out in the differential $\mathrm{O}_{3}+\mathrm{NO}_{2}$ measurement. However, it is possible that relative humidity differences in the two chambers can cause the $\mathrm{NO}_{2}$ removal and HONO off-gassing to be different in the two chambers. Thus, high relative humidity can introduce an artefact in the MOPS data.

With the current version of MOPS, therefore, we consider as valid only the data collected when the relative humidity is below 50\%. This condition is for the inside of the chambers and not for the ambient air. In daytime, the temperature inside the chambers is higher than ambient by $5-11^{\circ} \mathrm{C}$, which makes the relative humidity inside the chambers drop about $25 \%$ with respect to ambient. Hence, the MOPS can measure ozone production without introducing an artefact in the measurements at ambient relative humidities as much as $75 \%$ as long as the relative humidity inside the chambers stays below $50 \%$. Fortunately, the relative humidity inside the chambers is lower than $50 \%$ for much of the daytime conditions under which ozone production is greatest, so that the current version of MOPS can measure ozone production without artefacts during these polluted conditions.

\subsubsection{Sensitivity, time constant and absolute uncertainty}

The exposure time of the air inside the chambers is directly related to the sensitivity and detection limit of the instrument. Analysis of the MOPS signals indicates that the detection limit of the instrument corresponds to $0.06 \mathrm{ppbv}$ for a 10-min integration. This detection limit corresponds to $0.67 \mathrm{ppbv} \mathrm{h}^{-1}$ for the 10 -min average data. A fast check of 


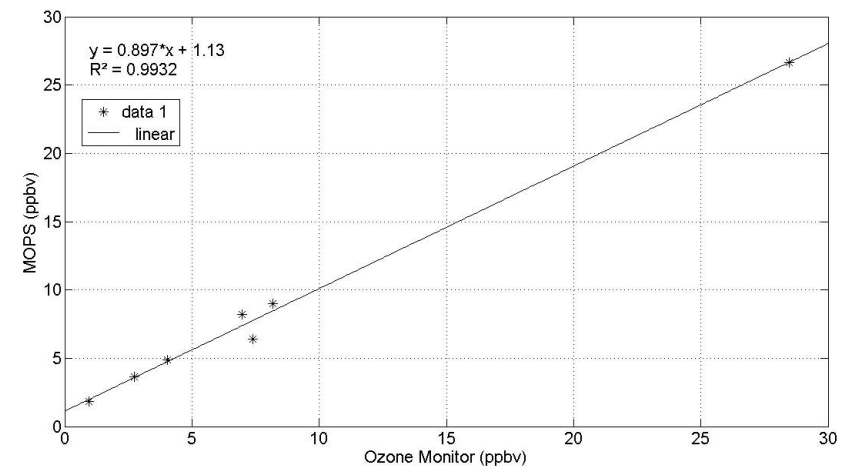

Fig. 3. Ozone differences seen by MOPS as a function of differences seen by a Thermo Scientific 49i ozone monitor.

the level of sensitivity needed to measure urban ozone production can be done using the chemical production terms of Eq. (1) with atmospheric values for the species $\mathrm{NO}, \mathrm{HO}_{2}$ and $\mathrm{RO}_{2}$. For example, for conservatively low levels of pollutants such as $10 \mathrm{pptv}$ for the sum $\left[\mathrm{HO}_{2}+\mathrm{RO}_{2}\right], 0.5 \mathrm{ppbv}$ for [NO], and an effective rate coefficient of approximately $5 \times 10^{-12}$ $\left(\mathrm{cm}^{3}\right.$ molecules $\left.{ }^{-1} \mathrm{~s}^{-1}\right)$, the rate of ozone production is approximately $2.1 \mathrm{ppbv} \mathrm{h}^{-1}$. For highly polluted conditions, the ozone production rate can be in the range of $50 \mathrm{ppbv} \mathrm{h}^{-1}$. So, although the current MOPS is not sensitive enough to detect ozone production rates in the remote atmosphere, the MOPS detection limit of $0.67 \mathrm{ppbv} \mathrm{h}^{-1}$ for the 10 -min average is sufficient to measure even low ozone production rates in urban and suburban air. The signal-to-noise ratio during the ozone production maximum is typically $20-30$.

The main sources of uncertainty in the measurement of ozone production are the accuracy of the ozone differential measurement and the uncertainty in the determination of mean exposure time. The accuracy of the MOPS ozone differential measurement was determined experimentally. Two ozone mixtures were prepared and their concentrations were measured using an ozone monitor (Thermo Scientific 49i). The difference in mixing ratios between the two mixtures was determined with the same ozone monitor without the ozone scrubber. As a next step, the same two ozone mixtures were connected to the MOPS instrument in its operating mode. Figure 3 shows the ozone difference seen by MOPS as a function of the difference seen by the ozone monitor. The slope of the line is 0.90 and the mean of the ratio of the MOPS differential relative to the ozone monitor differential is $1.22 \pm 0.31(95 \%, N=7)$. Thus, the uncertainty in the differential ozone measurement is approximately $\pm 25 \%$ $(95 \%, N=7)$. The uncertainty in the mean exposure time was obtained from the estimate of error in the pulse experiments and reaction experiments and is $\pm 5 \%$. The uncertainty introduced by differences in relative humidity is $\pm 14 \%$ for the early morning data. Other factors, such as the temperature difference between the sample and reference cham- bers and ambient, contribute additional estimated uncertainty of $\pm 10 \%$. Thus, the absolute uncertainty ( $95 \%$ confidence level) of the current MOPS measurement is $\pm 30 \%$ for daytime operating conditions and $\pm 35 \%$ for data that could be affected by relative humidity such as in the early morning.

\section{Test results}

The first version of the MOPS instrument was tested on the University Park campus of the Pennsylvania State University in the late summer of 2008. The preliminary tests were performed on the roof of Walker Building, $30 \mathrm{~m}$ above one of the main streets in State College, PA. The air in this location corresponds to a rural background atmosphere disturbed by spikes of pollution from the traffic on the road below during rush hour.

Figure 4 shows the data collected during 1 to 4 September 2008. From the shape and magnitude of some of the NO spikes, it is evident that the MOPS was sampling fresh emission plumes coming from vehicles on the main road. The ozone production rate follows NO, peaking at the same time, in particular for 1 and 4 September. These two days are characterized by similar NO emission peaks. 2 September was characterized by a plume of emissions with very high NO concentrations. In this case the ozone production was rather low when the NO was the highest, above $30 \mathrm{ppbv}$. These plots showed early evidence of the existence of a correlation between $P\left(\mathrm{O}_{3}\right)$ and NO for these particular conditions, although not enough ancillary meaurements, particularly of radicals, were made to draw conclusions (Ren et al., 2003). These results, however, do indicate that this instrument could potentially clarify the discrepancies in the calculated ozone production rates from measured and modeled $\mathrm{HO}_{2}$.

These first tests demonstrate the feasibility of the MOPS technique. The instrument responded physically to the presence of solar radiation and ozone precursors and yielded rates of ozone production in ranges that are within expected values for a polluted rural environment. In addition to being able to collect ambient measurements, these preliminary studies show that the MOPS can be used to investigate further the correlation between $P\left(\mathrm{O}_{3}\right)$ and $\mathrm{NO}$ by adding precursors to the ambient air through both chambers and observing the effect on the production of ozone.

\section{Conclusions}

The direct measurement of ozone production rates in the atmosphere is feasible. The MOPS separates the ozoneproducing photochemistry from the non-producing photostationary state (PSS) of $\mathrm{NO}, \mathrm{NO}_{2}$ and $\mathrm{O}_{3}$, to detect the formation rate of "new ozone". Laboratory tests demonstrate that the abundance of peroxy radicals in the MOPS sample chamber is similar to the atmosphere while these radicals are 

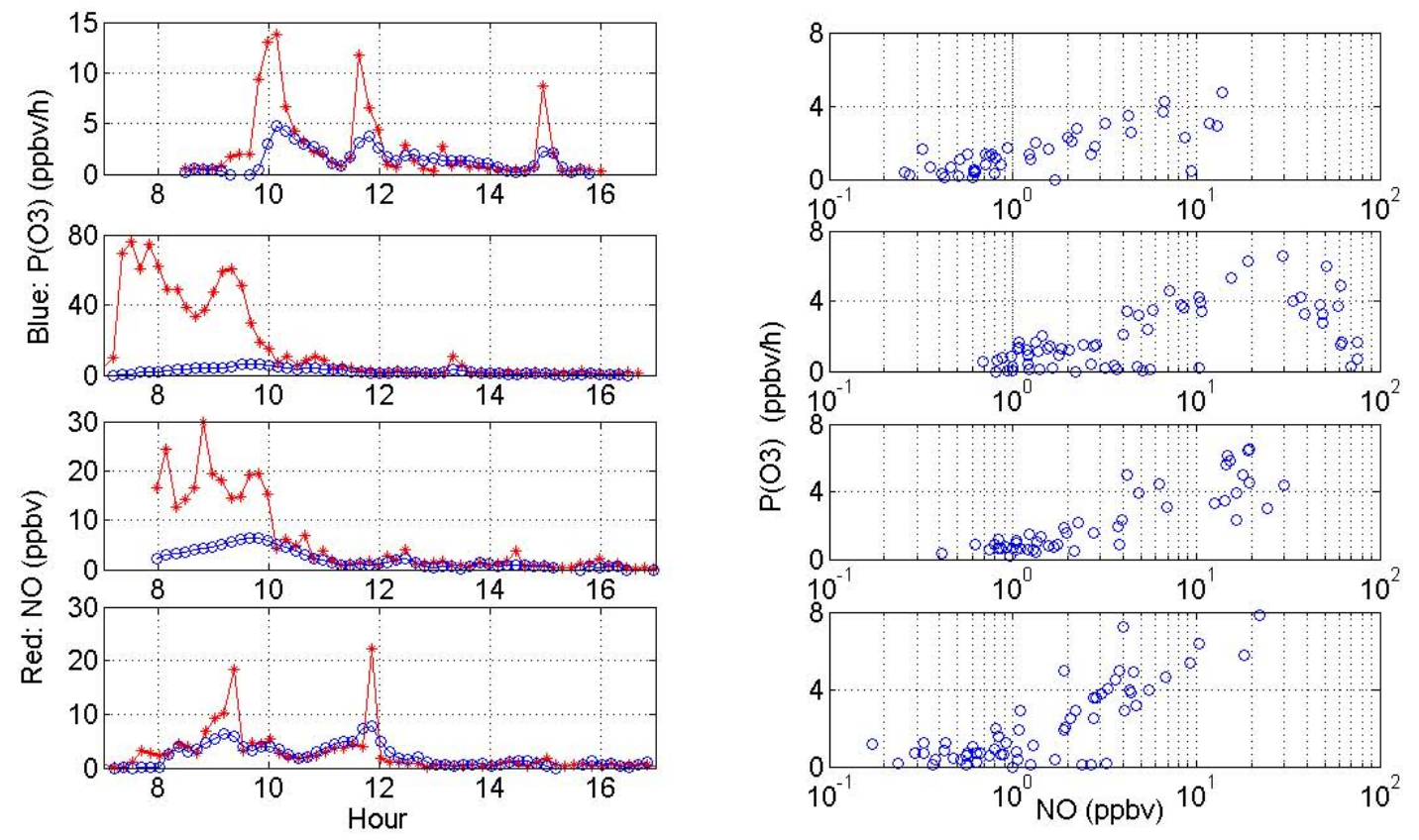

Fig. 4. Rates of ozone production measured on the campus of the Pennsylvania State University during 1 to 4 September 2008 . The left column contains time series for $P\left(\mathrm{O}_{3}\right)$ (blue circles) and NO (red stars) for every day starting on Sep 1 and ending on 4 September 2008. The right column is the correlation between measured $P\left(\mathrm{O}_{3}\right)$ and ambient NO.

virtually not present in the reference chamber. These conditions ensure that the differential of ozone between chambers yields the measurement of the ozone produced by reactions between peroxy radicals and NO only. The tests performed on the current version of MOPS, therefore, indicate that the instrument works correctly for the detection of ozone production rates.

The detection limit of the current MOPS is $0.67 \mathrm{ppbv} \mathrm{h}^{-1}$ for the 10-min average data. This limit can be lowered by improving the sensitivity of the detection cells. A better sensitivity of detection would enable the use of smaller sample and reference chambers and shorter exposure times.

At the $95 \%$ confidence level, the absolute uncertainty of the instrument is $30 \%$ for measurements not affected by relative humidity. For early morning data, the uncertainty increases to $35 \%$ at the same confidence level. The uncertainties in the measurement can be reduced, in part, by minimizing wall effects that cause $\mathrm{NO}_{2}$ losses. One possibility is to improve the flow pattern in the chambers so that the motion resembles more closely plug flow. Methods of improving the flows are now being studied.

The MOPS is an inexpensive instrument that, when added to air quality networks, would greatly enhance the understanding of ozone pollution issues in urban and suburban environments. The MOPS retrieved the first experimental plots $P\left(\mathrm{O}_{3}\right)$ vs. NO in early September 2008. The direct measurement of ozone production rates can contribute to the improvement of air quality regulations. Furthermore, the MOPS technique can be used to address the discrepancy between modeled and measured $\mathrm{HO}_{2}$. A first step towards elucidating these discrepancies would be the deployment of the MOPS instrument along with the Ground-based Tropospheric Hydrogen Oxides Sensor (GTHOS) to collect data over a period of time and compare the ozone production rates calculated from modeled and measured $\mathrm{HO}_{2}$. The instrument can also be used to quantify the importance of locally produced ozone versus transported ozone. Finally, sensitivity analysis can be performed with the MOPS by adding NO to the ambient air to provide an indicator of $\mathrm{NO}_{\mathrm{x}}$ sensitivity to ozone production.

Acknowledgements. The authors thank the College of Earth and Mineral Sciences at the Pennsylvania State University for the Miller Faculty Fellowship, which provided graduate student support for M. C. and funds for the fabrication of MOPS. NSF grant ATM-0209972 supported the initial development of MOPS. We also thank B. Lefer and J. Flynn for measuring the photolysis frequencies in May 2009 in Houston, D. van Duin and X. Ren for help with the radical chamber studies, and K. Biddle and the EMS machine shop for MOPS fabrication help.

Edited by: D. Heard 


\section{References}

Faloona, I. C., Tan, D., Lesher, R. L., Hazen, N. L., Frame, C. L., Simpas, J. B., Harder, H., Martinez, M., Di Carlo, P., Ren, X., and Brune, W. H.: A laser induced fluorescence instrument for detecting tropospheric $\mathrm{OH}$ and $\mathrm{HO} 2$ : Characteristics and calibration, J. Atmos. Chem., 47, 139-167, 2004.

Finlayson-Pitts, B. J. and Pitts Jr., J. N.: The chemical basis of air quality: Kinetics and mechanism of photochemical air pollution and application to control strategies, Advances in Environmental Science and Technology, edited by: Pitts Jr., J. N. and Metcalf, R. L., New York, USA, Wiley-Interscience Publication, 75-162, 1977.

Forster, P., Ramaswamy, V., Artaxo, P., Berntsen, T., Betts, R., Fahey, D. W., Haywood, J., Lean, J., Lowe, D. C., Myhre, G., Nganga, J., Prinn, R., Raga, G., Schulz, M., and Van Dorland, R.: Changes in Atmospheric Constituents and in Radiative Forcing. In: Climate Change 2007: The Physical Science Basis. Contribution of Working Group I to the Fourth Assessment Report of the Intergovernmental Panel on Climate Change, edited by: Solomon, S., Qin, D., Manning, M., Chen, Z., Marquis, M., Averyt, K. B., Tignor, M., and Miller, H. L., Cambridge University Press, Cambridge, United Kingdom and New York, NY, USA, 150-152, 2007.

Gégo, E., Porter, P. S., Gilliland, A., and Rao, S. T.: ObservationBased assessment of the impact of Nitrogen Oxides emissions reductions on ozone air quality over the Eastern United States, J. Appl. Meteor. Clim., 46, 994-1008, 2007.

Gery, M. W., Whitten, G. Z., Killus, J. P., and Dodge, M. C.: A photochemical kinetics mechanism for urban and regional scale computer modeling, J. Geophys. Res., 94, 12925-12956, 1989.

Haagen-Smit, A. J., Bradley, C. E., and Fox, M. M.: Ozone formation in photochemical oxidation of organic substances, Ind. Eng. Chem., 45, 2086-2089, 1953.

Ho, W. C., Hartley, W. R., Myers, L., Lin, M. H., Lin, Y. S., Lien, C. H., and Lin, R. S.: Air pollution, weather, and associated risk factors related to asthma prevalence and attack rate, Environ. Res., 104, 402-409, 2007.

Kanaya, Y., Cao, R., Akimoto, H., Fukuda, M., Komazaki, Y., Yokouchi, Y., Koike, M., Tanimoto, H., Takegawa, N., and Kondo, Y.: Urban photochemistry in central Tokyo: 1. Observed and modeled $\mathrm{OH}$ and $\mathrm{HO}_{2}$ radical concentrations during the winter and summer of 2004, J. Geophys. Res., 112, D21312, doi:10.1029/2007JD008670, 2007.

Kemball-Cook, S., D. Parrish, T. Ryerson, U. Nopmongcol, J. Johnson, E. Tai, and Yarwood, G.: Contributions of regional transport and local sources to ozone exceedances in Houston and Dallas: Comparison of results from a photochemical grid model to aircraft and surface measurements, J. Geophys. Res., 114, D00F02, doi:10.1029/2008JD010248, 2009.

Kleinman, L. I., Daum, P. H., Lee, Y. -N., Nunnermacker, L., Springston, S. R., Newman L., Weinstein-Lloyd, J., and Sillman, S.: Dependence of ozone production on NO and hydrocarbons in the troposphere, J. Geophys. Res., 24, 2299-2302, 1997.

Kleinman, L. I., Daum, P. H., Lee, Y.-N., Nunnermacker, L., and Springston, S. R.: Ozone production efficiency in an urban area, J. Geophys. Res., 107(D23), 4733, doi:10.1029/2002JD002529, 2002.

Kleinman, L. I.: The dependence of tropospheric ozone production rate on ozone precursors, Atmos. Environ., 39, 575-586, 2005.
Logan, J. A., Prather, M. J., Wofsy, S. C., and McElroy, M. B.: Tropospheric Chemistry: A global perspective, J. Geophys. Res., 86, 7210-7254, 1981.

Madden, M. C. and Hogsett, W. E.: A Historical Overview of the Ozone Exposure Problem, Human Ecol. Risk Assess., 7(5), 1121-1131, 2001.

Martinez, M., Harder, H., Kovacs, T. A., Simpas, J. B., Bassis, J., Lesher, R., Brune, W. H., Frost, G. J., Williams, E. J., Stroud, C. A., Jobson, B. T., Roberts, J. M., Hall S., R., Sheter, E., Wert, B., Fried, A., Alicke, B., Stutz, J., Young, V. L., White A. B., and Zamora, R. J.: $\mathrm{OH}$ and $\mathrm{HO}_{2}$ concentrations, sources, and loss rates during the Southern Oxidants Study in Nashville, Tennessee, summer 1999, J. Geophys. Res., 108(D19), doi:10.1029/2003JD003551, 2003.

National Research Council (NRC): Rethinking the ozone problem in urban and regional air pollution, Natl. Acad. Press, 109-186, 1991.

Ren, X., Harder, H., Martinez, M., Lesher, R., Oliger, A., Simpas, J., Brune, W., Schwab, J., Demerjian, K., He, Y., Zhou, X., and Gao, $\mathrm{H} .: \mathrm{OH}$ and $\mathrm{HO}_{2}$ Chemistry in the urban atmosphere of New York City, Atmos. Environ., 37, 3639-3651, 2003.

Ren, X. R., Harder, H., Martinez, M., Faloona, I. C., Tan, D., Lesher, R. L., Di Carlo, P., Simpas, J. B., and Brune, W. H.: Interference testing for atmospheric $\mathrm{HO}_{\mathrm{x}}$ measurements by laserinduced fluorescence, J. Atmos. Chem., 47, 169-190, 2004.

Sander, S. P., Friedl, R. R., Golden, D. M., Kurylo, M. J., Moortgat, G. K., Wine, P. H., Ravishankara, A. R., Kolb, C. E., Molina, M. J., Finlayson-Pitts, B. J., Huie, R. E., and Orkin, V. L.: Chemical kinetics and photochemical data for use in atmospheric studies, Evaluation Number 15, JPL Publication 06-2, NASA Jet Propulsion Laboratory, Pasadena, CA, USA, 2006.

Shetter, R. E. and Müller, M.: Photolysis frequency measurements using actinic flux spectroradiometry during the PEM-Tropics mission: Instrumentation description and some results, J. Geophys. Res., 104, 5647-5661, 1999.

Shetter, R. E., Cinquini, L., Lefer, B. L., Hall, S. R., and Madronich, S.: Comparison of airborne measured and calculated spectral actinic flux and derived photolysis frequencies during the PEM Tropics B mission, J. Geophys. Res., 108(D2), 8234, doi:10.1029/2001JD001320, 2003.

Shirley, T. R., Brune, W. H., Ren, X., Mao, J., Lesher, R., Cardenas, B., Volkamer, R., Molina, L. T., Molina, M. J., Lamb, B., Velasco, E., Jobson, T., and Alexander, M.: Atmospheric oxidation in the Mexico City Metropolitan Area (MCMA) during April 2003, Atmos. Chem. Phys., 6, 2753-2765, 2006, http://www.atmos-chem-phys.net/6/2753/2006/.

Sillman, S.: Tropospheric ozone: the debate over control strategies, Ann. Rev. Ener. Environ., 18, 31-53, 1993.

Sillman, S.: The use of $\mathrm{NOy}, \mathrm{H}_{2} \mathrm{O}_{2}$, and $\mathrm{HNO}_{3}$ as indicators for ozone- $\mathrm{NO}_{\mathrm{X}}$-hydrocarbon sensitivity in urban locations, J. Geophys. Res., 100, 14175-14188, 1995.

Svensson, R., Ljungstrom, E., and Lindqvist, O.: Kinetics of the reactions between nitrogen dioxide and water vapor, Atmos. Environ., 21, 1529-1539, 1987.

Taubman, B. F., Thompson, A. M., Fuentes, J. D., Joseph, E., Michaels, S. M., Robjhon, M., and Piety, C. A.: The MidAtlantic low level jet and its implications for air quality, J. Geophys. Res., doi:2008JD009798, submitted, 2009.

Tonnesen, G. S. and Dennis, R. L.: Analysis of radical propagation 
efficiency to asses ozone sensitivity to hydrocarbons and $\mathrm{NO}_{\mathrm{x}}: 1$. Local Indicators of Odd Oxygen Production sensitivity, J. Geophys. Res., 105, 9213-9225, 2000.

Tonnesen, G. S. and Dennis, R. L.: Analysis of radical propagation efficiency to asses ozone sensitivity to hydrocarbons and $\mathrm{NO}_{\mathrm{x}}$ : 2. Long lived species as indicators of ozone concentration sensitivity, J. Geophys. Res., 105, 9227-9241, 2000.
Wainman, T., Wescheler C. J., Lioy, P. J., and Zhang, J.: Effects of surface type and relative humidity on the production and concentration of nitrous acid in a model indoor environment, Environ. Sci. Technol., 35, 2200-2206, 2001. 